Magdalena Sobocińska (iD https://orcid.org/0000-0002-5231-2511

Uniwersytet Ekonomiczny we Wrocławiu

e-mail: magdalena.sobocinska@ue.wroc.pl

\title{
Tożsamość, rola i mit artysty jako uwarunkowania jego wizerunku
}

\author{
Abstract

\section{Identity, Role and Myth of the Artist as a Conditions of It's Image}

Together with the development of market orientation in the sphere of culture, the questions concerning the strategy and instruments of creation of the image of cultural institutions and artists, as well as their effectiveness are more and more frequently formulated in the discourse on art. This also has impact on development of new media that on the one hand expand the possibilities of artists' communication with culture recipients, and on the other hand make the artist's image increasingly more shaped by the users of new media. Furthermore, it must be emphasised that on the grounds of marketing, the image is perceived in terms of a resource. The goal of the paper is to show the multitude of factors that shape the artist's image. The considerations in the paper are conducted while taking into consideration the dimensions of identities, as well as myths associated with artists' work shaped in recipients' awareness. A model of determinants shaping the artist's image is the result of the considerations and analyses. The paper is based on literature studies and semiotic approach contained in the stream of qualitative research.

Keywords: cultural market, identity, artist's image, determinants shaping the artist's image

Słowa kluczowe: rynek kultury, tożsamość, wizerunek artysty, czynniki kształtujące wizerunek artysty

\section{Wprowadzenie}

W zarządzaniu sferą kultury ważne miejsce zajmuje znalezienie właściwych form wyrażenia tożsamości artysty i w konsekwencji zbudowanie jego wyrazistego wizerunku. Wiąże się to z implementacją na grunt sfery kultury podejścia marketingowego, 
którego stosowanie powinno uwzględniać specyfikę i funkcje kultury, a także potrzeby artystów. Jednocześnie należy zauważyć, że w dobie procesów ekonomizacji kultury i rozwoju przemysłów kreatywnych wizerunek traktowany jest w kategoriach zasobu. Analiza literatury przedmiotu pozwala na identyfikację luki badawczej w kwestii znaczenia tożsamości artysty oraz jego roli i związanych z nim mitów w złożonym zbiorze uwarunkowań jego wizerunku. Celem artykułu jest ukazanie relacji między tożsamością artysty a jego wizerunkiem oraz wskazanie na wielość czynników kształtujących ów wizerunek. Tak sformułowany cel wymaga ukazania istoty i funkcji tożsamości, a także ról pełnionych przez artystów oraz związanych z nimi mitów, które funkcjonują w świadomości społecznej i wpływają na postrzeganie twórców. Szczególna uwaga poświęcona została analizie zmieniających się kodów kulturowych dotyczących twórców. Efektem rozważań, prowadzonych na podstawie studiów literaturowych wzbogaconych o zastosowanie podejścia semiotycznego, jest teoretyczny model czynników kształtujących wizerunek artysty.

\section{Toissamość i wizerunek artysty - przeğląd literatury}

Punktem wyjścia w procesie budowania wizerunku artysty jest analiza jego tożsamości, której zrozumienie pozwala dostosować formy komunikacji i tak kształtować wizerunek twórcy, aby nie powstawała zbyt duża luka między tożsamością i jej odbiorem przez podmioty otoczenia, w tym uczestników kultury.

Odwołując się do dorobku psychologii i socjologii, należy zauważyć, że tożsamość każdego człowieka posiada wymiar indywidualny oraz społeczno-kulturowy, ponieważ historia życia jednostki rozwija się na płaszczyźnie horyzontalnej, w czasie, a także wertykalnej, związanej z przynależnością jednostki do określonych struktur społecznych. Jednostka odczuwa kontekst społeczno-kulturowy przez wielość spełnianych ról społecznych, a niekiedy także sprzeczność, jakiej doświadcza, stykając się z oczekiwaniami dotyczącymi jej zachowań. Osobista historia jednostki jest uwarunkowana historią jej rodziny, społeczeństwa, narodu i państwa, kręgu cywilizacyjnego, regionu geograficznego i etnograficznego - przechowywaną w pamięci zbiorowej i stanowiącą podstawę do kształtowania się tożsamości jednostki. Należy podkreślić, że o ile pamięć o wydarzeniach rozwinięta w małym stopniu przekłada się na problemy z kształtowaniem się tożsamości jednostki, o tyle pamięć wysoce rozwinięta tworzy bogatą podstawę do formowania się owej tożsamości, ale niesie ze sobą również ryzyko resentymentów i nadmiernej koncentracji na przeszłości oraz wielu obaw przed przyszłością. Warunkiem prawidłowego funkcjonowania jednostki jest zatem integracja trzech perspektyw czasowych, czyli przeszłości, teraźniejszości i przyszłości. Proces budowania tożsamości wiąże się z takimi kategoriami jak: wartości mające wpływ na postępowanie jednostki, jej osobowość, indywidualność, unikatowość, a także przynależność do określonych grup społecznych. Należy 
podkreślić, że funkcją tożsamości jest określanie miejsca jednostki w wymiarze społecznym oraz tworzenie jej niezależności opartej na odczuwaniu przez jednostkę własnej odrębności, ciągłości, integralności i identyczności, która wynika z pozostawania wiernym własnym ideałom niezależnie od okoliczności zewnętrznych. Tożsamość umożliwia jednostce zbudowanie poczucia własnej wartości, a także uzyskanie akceptacji społecznej [Brzezińska 2006: 47-77]. Jednocześnie należy zauważyć, że twórcy nie tylko budują swoją tożsamość, ale poprzez swoje dzieła oraz postępowanie odgrywają istotną rolę w kształtowaniu tożsamości innych osób. Od sposobów wyrażania przez artystów własnej tożsamości zależy to, jak są postrzegani przez odbiorców kultury, innych twórców i recenzentów. Tożsamość jest zatem wartością pierwotną w stosunku do wizerunku.

W naukach ekonomicznych pod pojęciem wizerunku rozumie się wyobrażenie czy też opinię o określonym podmiocie rynku. Takie określenie jest dość uniwersalne i może dotyczyć także twórców. Do cech wizerunku zalicza się:

- treść, która związana jest z przedmiotem postawy,

- kierunek dotyczący pozytywnego lub negatywnego stosunku do przedmiotu postawy,

- trwałość,

- zakres związany z liczbą obiektów, których dotyczy [Witczak 1998: 7].

Warto dodać, że występuje wiele modeli tożsamości i wizerunku marki, wśród których w szczególności należy zwrócić uwagę na sześciokąt tożsamości marki Kapferera [Kapferer 2008: 183]. Na model ten składają się trzy perspektywy, które są tworzone przez obraz nadawcy, połączony „wyrazem zewnętrznym” i „wyrazem wewnętrznym" z obrazem odbiorcy. Koncepcja ta została już zaimplementowana na grunt marki instytucji kultury [Smoleń 2017: 365-372].

Wśród mechanizmów powstawania wizerunku należy wskazać na jego generalizację na podstawie pojedynczych faktów, zdarzeń i doświadczeń. Kolejnym mechanizmem jest zjawisko aureoli, czyli przenoszenia ogólnego wizerunku na poszczególne kwestie związane z podmiotem, jak również stabilizacja wizerunku, co oznacza jego utrzymywanie się mimo zmiany czynników, które w przeszłości kształtowały wizerunek [Wojcik 2005: 41-50].

Aktywne podejście do kształtowania wizerunku wiąże się z przyjmowaniem długofalowej perspektywy i uwzględnieniem etapów polegających na zidentyfikowaniu jego adresatów oraz określeniu pożądanego wizerunku w odniesieniu do tożsamości, a następnie na jej komunikowaniu wraz ze zdefiniowaniem możliwych barier i zakłóceń pożądanego wizerunku. Kolejnym krokiem w procesie kreowania wizerunku jest pomiar uzyskanych efektów, który stanowi punkt wyjścia do dalszych działań związanych z zarządzaniem wizerunkiem [Dewalska-Opitek 2010: 219-229].

Należy podkreślić, że wizerunek, będący następstwem tego, w jaki sposób artysta wyraża swoją tożsamość, stanowi sumę wiedzy, doświadczeń, wrażeń i przekonań oraz odczuć [Worcester 1986: 601-616], które u uczestników kultury i innych 
podmiotów rynku wiążą się z danym artystą. Na kategorię tożsamości i wizerunku artysty warto spojrzeć przez pryzmat pełnionych przez niego funkcji, do których zalicza się m.in.:

- rolę „artysty - demiurga”, stwarzającego nowe idee i wartości, formy, treści oraz sensy i znaczenia,

- rolę „artysty - sługi sztuki”, jako swoistej świętości, kogoś pośredniczącego między człowiekiem a transcendencją,

- rolę „artysty - proroka”, który przestrzega przed nadejściem niebezpieczeństw, zagrożeń,

- rolę „artysty - mędrca”, który dochodząc prawdy, prowadzi rozważania na temat tego, co jest dobre, a co złe,

- rolę „artysty - reformatora”, chcącego naprawiać świat,

- rolę „artysty - estety” upiększającego świat i dostarczającego odbiorcom przyjemności wynikających z obcowania z pięknem [Golka 2013: 326].

Należy mieć na uwadze, że oprócz pełnionych przez twórców ról, wyrażających ich tożsamość, kształtowanie się wizerunku artystów uzależnione jest od mitów, które choć nie zawsze dobrze oddają sytuację współczesnego artysty, to jednak funkcjonują w świadomości społecznej. Zalicza się do nich między innymi mit wyjątkowości artysty, mit indywidualizmu artysty, mit geniuszu artystycznego, mit wrażliwości artysty, mit cierpienia i odrzucenia artysty, mit bezinteresowności tworzenia sztuki, mit wolności [Golka 2013: 325] (por. tabela 1).

Tabela 1. Rodzaje mitów dotyczących artystów

\begin{tabular}{|l|l|}
\hline \multicolumn{1}{|c|}{ Typ mitu } & \multicolumn{1}{c|}{ Istota mitu } \\
\hline Mit wyjątkowości & Artysta różni się od pozostałych ludzi, a jego odmienność jest nadzwyczajna \\
\hline Mit indywidualności & $\begin{array}{l}\text { Artyści także w swojej grupie nie są powtarzalni i trudno ich porównywać między } \\
\text { sobą }\end{array}$ \\
\hline Mit powołania & Artysta ma talent, który ujawni się niezależnie od okoliczności i woli innych osób \\
\hline Mit bezinteresowności & $\begin{array}{l}\text { Sztuka jest wartością autoteliczną, a proces twórczy wolny jest od motywacji } \\
\text { ekonomicznych }\end{array}$ \\
\hline Mit wolności & $\begin{array}{l}\text { Artysta jest ponad różnego typu ograniczeniami zarówno na płaszczyźnie arty- } \\
\text { stycznej, jak i w zakresie stylu życia }\end{array}$ \\
\hline Mit cierpienia & Tworzenie związane jest z udręką \\
\hline Mit odrzucenia & $\begin{array}{l}\text { Artysta nie spotyka akceptacji społecznej. On i jego twórczość nie są właściwie } \\
\text { rozumiane }\end{array}$ \\
\hline
\end{tabular}

Opracowano na podstawie: Golka 2013: 325. 
Jednocześnie należy zauważyć, że ze względu na dokonujące się przemiany zarówno w sztuce, jak i w społeczeństwie oraz gospodarce niektóre z mitów tracą, a inne zyskują na znaczeniu. Istnieje zatem potrzeba rozpoznania zmian kodów kulturowych dotyczących artystów. Użyteczne w tym zakresie jest podejście semiotyczne.

\section{Semiotyka jako podejscie badawcze slużące identyfikacji kodów kulturowych dotyczących artysty}

$\mathrm{W}$ identyfikacji wizerunku artysty znajduje zastosowanie podejście semiotyczne, którego istota polega na tym, że badany jest kontekst, w jakim odbywają się procesy tworzenia i recepcji kultury. Badania semiotyczne, mieszczące się w nurcie badań jakościowych, służą identyfikacji poziomów znaczeń pojęć i sposobów ich kategoryzacji, jak również rozpoznawaniu uwarunkowanych kulturowo postaw i zachowań [Harvey, Evans 2001: 171-187, Mazurek-Łopacińska, Sobocińska 2014: 11-21, Mazurek-Łopacińska 2015: 26-36]. W badaniach semiotycznych szczególną rolę pełnią teksty kultury, w tym literatura, filmy, programy telewizyjne, prasa, reklama. W badaniach tych odchodzi się od deklaratywnych wypowiedzi na rzecz analizy elementów kultury, które kształtują zachowania konsumentów.

Specyfikę podejścia semiotycznego można przedstawić przez pryzmat przyjętych w nim założeń, do których zalicza się m.in. to, że:

- każdy obraz, tekst zawiera wiele warstw znaczeniowych,

- charakter znaczeń zależy od kontekstu, w którym owe znaczenia występują; znaczenie ma zatem charakter relacyjny,

- niektóre warstwy znaczeniowe są względnie obiektywne, a inne nasycone są znaczeniami społecznymi [Baldwin et al. 2007: 77].

Obok analizy opozycji binarnych i kwadratu semiotycznego jednym z typów analiz semiotycznych jest analiza kodów kulturowych: rezydualnych, dominujących i emergentnych. U jej podstaw leży założenie, że kulturę danego okresu można opisać przez wewnętrzne relacje między wartościami rezydualnymi (ukształtowanymi w przeszłości, ale nadal obecnymi w kulturze) i wartościami dominującymi, czyli najbardziej popularnymi w danym okresie, a wartościami emergentnymi, dotyczącymi nowych znaczeń i praktyk, które zapowiadają kierunki zmiany kulturowej [Polak, Żurawicka 2015: 110-120]. Wyznaczenie trajektorii trendu pozwala na zrozumienie nie tylko tego, jaki był i jest konsument, lecz również jak będzie zmieniało się jego zachowanie w przyszłości, a także na zidentyfikowanie struktur znaczeniowych, którymi posługują się odbiorcy.

Dążąc do rozpoznania zmian zachodzących w zakresie wizerunku artysty, dokonano analizy tekstów kultury wyrażających założenia znamienne dla poszczególnych epok w literaturze. Skupino się na analizie tekstów zaliczanych do 
tzw. kanonu literatury, gdyż w największym stopniu kształtują one społeczne postrzeganie twórców. Uwzględniono także występujące już w tym zakresie analizy i aktualny dyskurs medialny oraz role, które pełnią w nim twórcy. Obraz artysty wyłaniający się w perspektywie semiotycznej wskazuje, że jest to kategoria podlegająca ewolucji. Biorąc pod uwagę kontekst epok w literaturze, malarstwie i dokonując pewnych uogólnień, należy podkreślić, że dla renesansu charakterystyczne jest ujmowanie artysty jako utalentowanego uczonego oraz odkrywcy. Dobrze obrazuje to przykład Leonarda da Vinci. W kolejnych epokach, a w szczególności w koncepcji romantycznej, określa się artystę mianem wyjątkowej jednostki genialnego kreatora o rozwiniętej duchowości, zainteresowanego mistyką oraz metafizyką, zmagającego się z wieloma przeciwnościami. W XIX wieku nastąpiło przejście od metafizycznej do psychologicznej interpretacji procesu twórczego, czego konsekwencją było traktowanie sztuki jako wykładnika osobowości artysty. Z kolei analiza manifestów awangardy europejskiej z początku XX wieku wskazuje, iż w tym typie dyskursu rosło znaczenie wolności absolutnej i wyzwolenia sztuki od przeszłości, tradycji, konwencji, instytucji kultury, przyzwyczajeń odbiorców. Towarzyszyła temu wiara w wynalazki techniczne oraz podnoszenie przedmiotów codziennego użytku do rangi sztuki, a także przejście od estetyki dzieła do estetyki działania. Ten model artysty zakładał odejście od pojęcia tożsamości budowanej esencjonalnie i zmieniającej się w linearny sposób ku podmiotowi podlegającemu fragmentaryzacji. Zbliżenie sztuki do publiczności miało na celu burzenie granic między artyzmem a utylitaryzmem oraz rozrywką [Popiel 2011: 49-74]. Obecnie $\mathrm{w}$ dyskursie dotyczącym kultury znaczące miejsce zajmuje profesjonalizacja pracy artysty i jego warsztat. Związane jest to z ekonomizacją kultury i rozwojem sektora kreatywnego, do którego zalicza się sektor kultury oraz przemysły kreatywne [Ilczuk 2012: 102-105]. Ponadto oprócz obrazu twórcy-profesjonalisty oraz intelektualisty ujawnia się także postrzeganie artysty w kategoriach osoby medialnej. Obserwuje się ponadto poszerzanie kategorii artysty oraz coraz częstsze włączanie do tej grupy np. youtuberów. Natomiast nowe kody kulturowe związane z artystą, określane zgodnie z podejściem semiotycznym jako emergentne, mają dychotomiczny charakter. Artysta $\mathrm{z}$ jednej strony zaczyna być postrzegany w kategoriach jego coraz silniejszych związków z nowymi technologiami, takimi jak np. rzeczywistość wirtualna, rozszerzona i mieszana, które otwierają nowe możliwości między innymi dla filmu, teatru, rzeźby, muzyki, a z drugiej w kontekście prac odchodzących od eksperymentów technologicznych i powiązań między sztuką a technologią. Trajektorię kodów kulturowych dotyczących artysty przedstawiono na rysunku 1.

Zaprezentowane zmiany w sposobie postrzegania artysty skłaniają do sformułowania pytania o czynniki wpływające na jego wizerunek. Jednocześnie należy zauważyć, że chociaż wizerunek jest skutkiem stosowanych przez artystę form komunikacji swojej tożsamości, to jednak istnieje wiele czynników determinujących wizerunek artysty, na które nie ma on wpływu lub ma wpływ jedynie pośredni. 


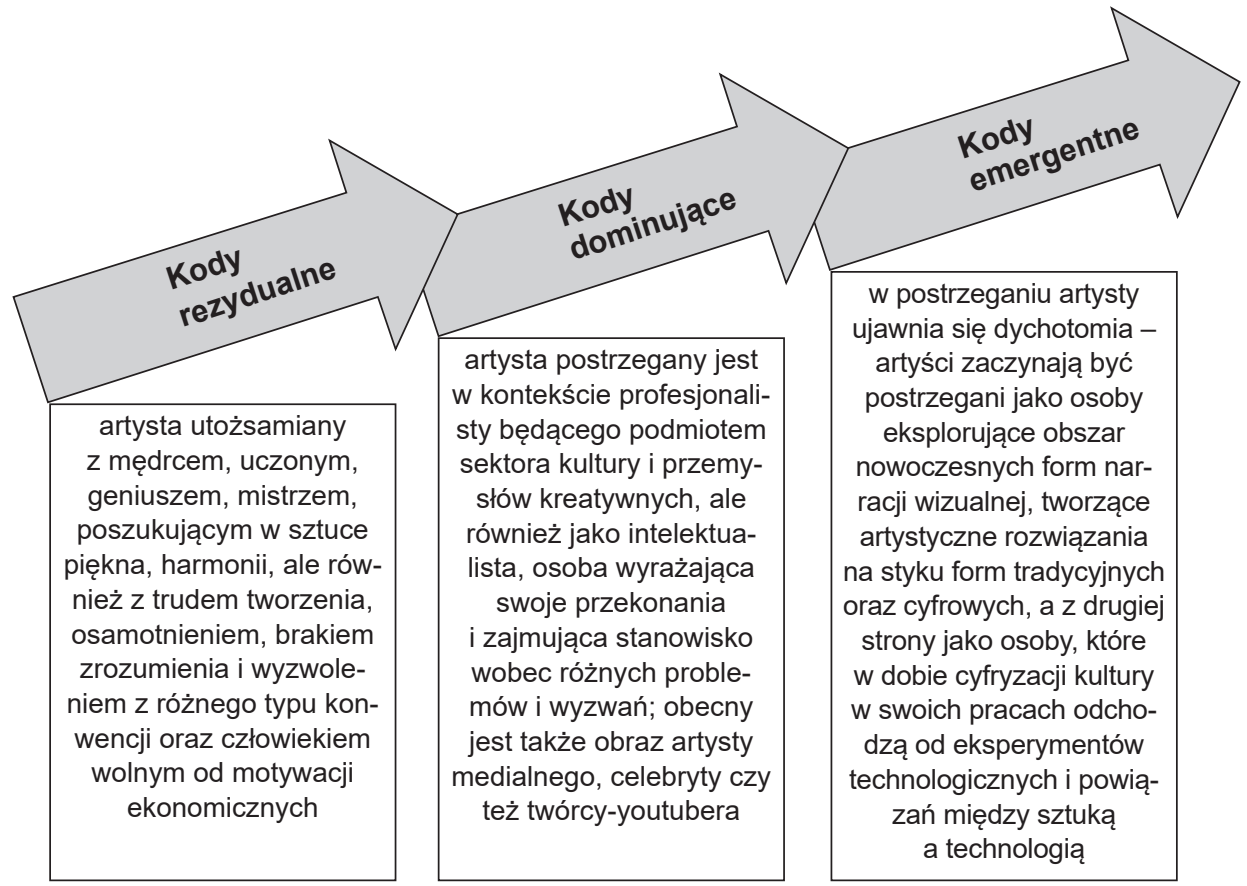

Rys. 1. Zmiany kodów kulturowych dotyczących artysty

Źródło: Opracowanie własne.

\section{Czynniki ksztaltujące wizerunek artysty - ujęcie modelowe}

Wśród czynników kształtujących wizerunek artysty szczególne miejsce zajmują tworzone przez niego dzieła, które służą wyrażaniu jego tożsamości. Ponadto do zależnych od twórcy czynników kreujących jego wizerunek zaliczyć należy reprezentowaną przez niego dziedzinę sztuki oraz pełnione funkcje, czy też osoby, z którymi artysta współpracuje. Wizerunek artysty uwarunkowany jest także jego stosunkiem do udziału w życiu społeczno-politycznym i zakresem zaangażowania w te kwestie. Mając na uwadze postępującą mediatyzację życia społecznego, należy wskazać także na to, iż wizerunek artysty kształtowany jest przez udzielane przez niego wywiady, $\mathrm{w}$ tym ich formę i treść. Ważny okazuje się także dobór mediów oraz częstość udzielania przez artystę wywiadów, gdyż konsekwencją nadmiaru informacji o artyście jest wywołanie u odbiorcy znużenia czy przesytu. Do czynników zależnych od artysty, które kształtują jego wizerunek, należy również wygląd i sposób ubierania się, który jednocześnie stanowi formę wyrażania tożsamości artysty.

Ponadto należy zauważyć, że istnieje szereg niezależnych wprost od artysty czynników kształtujących jego wizerunek. Jest to m.in. sposób postrzegania przez odbiorcę dziedziny sztuki, którą artysta reprezentuje, a także kompetencje kulturalne 
odbiorców, pozwalające im interpretować tworzone przez artystę dzieła, jak również profil publiczności i jej wizerunek. Na postrzeganie artysty mają też wpływ uzyskiwane przez niego nagrody, ich prestiż, jak również mity dotyczące twórców oraz inni artyści, gdyż odbiorcy kultury dokonują niejednokrotnie różnego typu porównań. Trzeba dodać, że o wizerunku artysty decyduje poziom zainteresowania nim mediów, a także wyrażane przez odbiorców opinie o artystach i ich twórczości. Jest to tym istotniejsze, że w dobie rozwoju Internetu, a w szczególności mediów społecznościowych, ich użytkownicy stają się współkreatorami wizerunku artysty. Warto również zaznaczyć, że na postrzeganie artysty wpływają różnice kulturowe, których znajomość jawi się jako istotne uwarunkowanie procesów komunikacji artysty z odbiorcami w podlegającym globalizacji świecie kultury. Czynniki kształtujące wizerunek artysty w ujęciu modelowym zaprezentowano na rysunku 2.

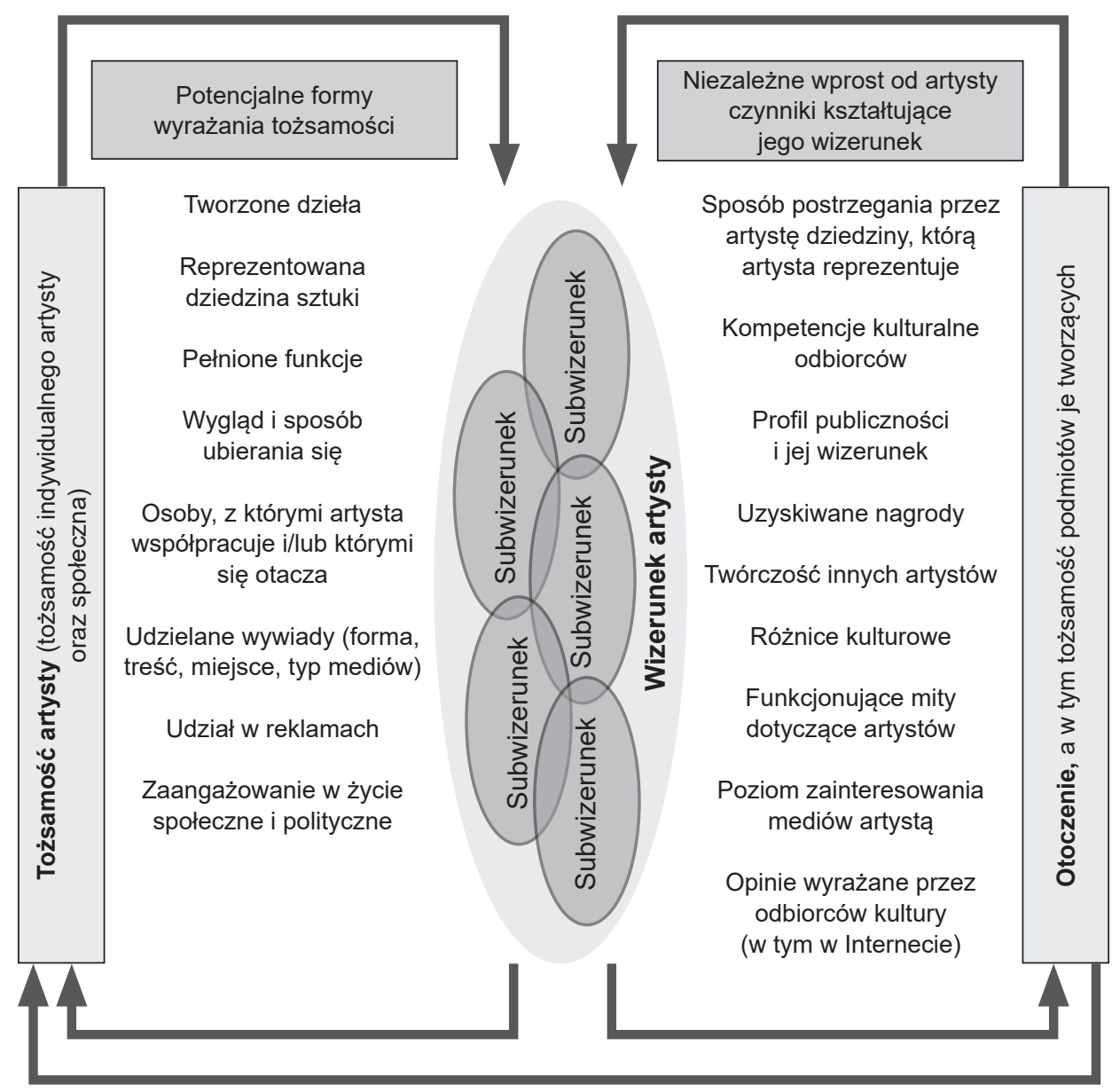

Rys. 2. Czynniki kształtujące wizerunek artysty - ujęcie modelowe

Źródło: Opracowanie własne. 
Kształtowanie wizerunku wymaga tego, aby w jak największym stopniu uwzględniać rzeczywiste cechy artysty oraz opierać się na jego najważniejszych umiejętnościach. Takie podejście jest zgodne z ujmowaniem roli marketingu w sferze kultury przez pryzmat znalezienia odpowiedniej widowni dla artysty i dzieł będących efektem jego pracy [Mokwa, Dawson, Prieve 1980]. Podobnie F. Colbert określając znaczenie marketingu w sferze kultury, zwraca uwagę, że jego stosowanie nie oznacza, że artysta tworząc dzieło ma dostosowywać się lub swoje postępowanie do oczekiwań i preferencji odbiorców. Marketing w kulturze definiuje się w kontekście docierania do segmentów rynku, które mogą być zainteresowane dziełem i artystą. Do specyfiki i profili odbiorców powinny być natomiast dostosowywane sposoby promocji oraz dystrybucji dzieła czy polityka cenowa. Przesłanką stosowania marketingu w sferze kultury jest bowiem umożliwienie konsumentom kontaktu ze sztuką i w konsekwencji osiąganie celów formułowanych przez artystów. Ponadto rola marketingu rozpatrywana jest pod kątem kształtowania gustów odbiorców, kreowania z nimi więzi, uwrażliwiania ich na kulturę, a nie tylko zaspokajania aktualnie odczuwanych potrzeb [Diggles 1986: 243, Colbert 2007: 4, 12, Dragićević-Šešić, Stojković 2010: 140-145, Varbanova 2013: 156-157, Sobocińska 2015: 89, Wróblewski 2017].

Elementem wizerunku jest imię i nazwisko, pseudonim artysty czy też nazwy formacji artystycznych, do których przynależy. Przyjęty pseudonim powinien w swoim znaczeniu i brzmieniu być zgodny z pożądanym wizerunkiem i posiadać osobiste odniesienia do artysty. W kreacji wizerunku znajduje także zastosowanie uczestnictwo twórcy w festiwalach i wydarzeniach medialnych. Na jego postrzeganie wpływa również sprzedaż w ramach merchandisingu produktów, na których widnieje jego podobizna. Istotne jest, aby były to takie produkty, które nie będą negatywnie wpływały na wizerunek artysty. Formą jego aktywności medialnej jest również udział w reklamie związanego $\mathrm{z}$ nim dzieła oraz innego typu produktów [Grzegorczyk, Kopeć 2013: 179-210]. W drugim przypadku uwzględniany jest nie tylko stopień rozpoznawalności danego artysty wśród przedstawicieli grupy docelowej reklamy i wywoływanej sympatii, lecz także zgodność pożądanego wizerunku produktu z wizerunkiem artysty. Stosunek artystów do udziału w reklamie jest dość zróżnicowany i chociaż część twórców nie chce wiązać się z reklamą, to jednak można wskazać bardzo wiele przykładów uznanych artystów, których wizerunek jest w reklamie wykorzystywany (Catherine Deneuve - Chanel, Yves Saint Laurent; Charlize Theron - Dior; Scarlett Johansson - Calvin Klein, Dolce \& Gabbana, L'Oréal, Louis Vuitton; Joanna Kulig - Reserved; Maja Ostaszewska i Magdalena Cielecka - W. KRUK; George Clooney - Nespresso).

Istotnym narzędziem wykorzystywanym w kreowaniu wizerunku artysty są posiadające wysoki prestiż nagrody. Warto jednak zauważyć, że rośnie liczba typów nagród. Obrazuje to przykład gry komputerowej Wiedźmin III, która zdobyła ponad 200 nagród jeszcze przed premierą. Należy podkreślić, że nagroda może być potwierdzeniem jakości czy wartości dzieła i artysty, ale też, wykorzystując rytualizację, 
tworzy wartość. Nagrody różnią się prestiżem, zasięgiem oddziaływania, medialnością, wykorzystywaną symboliką, a także tym, jaka grupa tworzy jury (krytycy, inni twórcy, konsumenci). Prowadzone w tym zakresie badania wskazują, że niejednokrotnie występuje zależność między odwołaniem się do nagrody a wzrostem sprzedaży biletów kinowych czy płyt. Dotyczy to np. nagrody muzycznej Grammy, której zdobywcy sprzedają znacznie więcej płyt niż nominowani, a różnica ta od 1984 roku zwiększa się. Przywołując z kolei przykład Nagród Akademii Filmowej należy wskazać, że nominacja filmu w kategorii najlepszego aktora i aktorki skutkuje wzrostem liczby ekranów, na których pokazywany jest film o $41 \%$, a w przypadku zdobycia w tej kategorii Oscara o 122\% [Anand, Watson 2004: 59-80, Deuchert, Adjamah, Pauly 2005: 159-176, Krzyworzeka 2017: 11-23].

Znaczenie nagród jako instrumentu kreowania wizerunku artysty ujawnia się w szczególności w kontekście multiplikacji ofert kulturalnych dostępnych w Internecie. Swego rodzaju nadmiar dzieł dostępnych w sieci sprawia, że różnicują się gusty i preferencje odbiorców kultury i w konsekwencji powstają kolejne subkultury, nisze odbiorców. Zważywszy na wielość bodźców kulturalnych oraz gromadzenie przez odbiorców na laptopach coraz większej liczby plików tekstowych i muzycznych oraz filmów, których niekiedy nawet nie będą mieli okazji przeczytać, wysłuchać, czy obejrzeć - istnieją problemy z selekcją nadmiaru treści. Zanikowi autorytetów, będących niegdyś swego rodzaju heurystykami ułatwiającymi dokonywanie wyborów, towarzyszy mnogość kanonów, czyli zestawów dzieł, które każdy powinien znać. Odbiorcy kultury przyjmują różne strategie postępowania w kulturze nadmiaru, a w tym strategię zawierzenia na przykład nagrodom, którymi dzieła zostały wyróżnione [Szlendak 2013: 16-22].

O niedoskonałej jednak przekładalności wynikającego z nagród kapitału symbolicznego i ekonomicznego świadczy np. to, że o ile w okresie od lat dwudziestych do sześćdziesiątych XX wieku prawie połowa książek, które zostały wyróżnione nagrodą Pulitzera, jednocześnie zaliczana była do najlepiej sprzedających się książek, o tyle od końca lat sześćdziesiątych tylko jedna na ponad trzydzieści nagrodzonych powieści stała się bestsellerem [English 2013: 226].

Z punktu widzenia ukazywania czynników kształtujących wizerunek artysty należy wskazać także na znaczenie skandali, które można rozpatrywać w wymiarze prowokacji artystycznej oraz walki politycznej i społecznej, wpisanej w historię sztuk plastycznych czy też teatru. Pierwsze przekazy o niestandardowych reakcjach na widowni zachowały się już z czasów antycznych. Znaczącym skandalem teatralnym siedemnastowiecznej Francji była premiera Tartufféa Molière’a. Odnosząc się do polskich realiów, należy wskazać na skandale teatralne związane z twórczością reżysera Leona Schillera. Za skandal kontrolowany uznawane jest przedstawienie Dziadów Mickiewicza w reżyserii Kazimierza Dejmka. Analiza skandali po roku 1989 wskazuje na poszerzanie pola kontrowersyjnych tematów, w skład którego wchodzą kwestie religijne, moralne, obyczajowe, ale również patriotyczne. Ponadto 
współczesnym skandalom towarzyszy niejednokrotnie rozgłos medialny [Pawłowski 2017: 110-124, Przastek 2017: 88-107]. Jednocześnie warto dodać, że w przypadku sfery kultury oraz kreowania wizerunku artysty skandal i związany z nim bojkot uczestników kultury może również być formą zaplanowanych działań marketingowych.

\section{Podsumowanie}

W kontekście prowadzonych $\mathrm{w}$ artykule rozważań i analiz powstaje pytanie o granicę swobody dokonywanej przez odbiorców interpretacji tożsamości artysty i jego dzieł oraz zakres nadawania znaczeń twórcom oraz dobrom kultury. Jest to także pytanie o związki między ludzką wolnością a władzą kultury i twórcy. Przyjęcie tezy, że odbiorcy mogą tworzyć dowolne znaczenia, pozbawia twórcę i dzieło autonomii. $\mathrm{W}$ takim ujęciu znaczenie nadawane twórcom i ich dziełom jest w całości wytworem umysłu odbiorcy. Wśród powodów, które sprawiają, że trudno jest przyjąć tezę o braku granic interpretacji, należy wskazać na to, że takie ujęcie kwestionuje kulturę jako wyobrażenie zbiorowe oraz odbiera jej funkcję komunikacyjną, a także utrwalającą więzi społeczne [Geertz 2005: 111]. Trudne jest także do przyjęcia drugie skrajne podejście, określane w kontekście „mitu jedynego właściwego znaczenia”, zgodnie z którym odbiorcy nie dysponują żadną swobodą interpretacji. Chociaż twórcom niekiedy może zależeć, aby ich dzieła czy postępowanie były interpretowane w określony sposób, to jednak niejednokrotnie to samo dobro kultury i artysta jest odbierany w różny sposób przez różne osoby [Griswold 2013: 125-139]. W związku z tym wydaje się, że nie można uznać zarysowanych dwóch skrajnych opcji dotyczących nadawania przez odbiorców artystom i dziełom znaczeń za właściwe i dobrze oddające to, w jaki sposób odbiorcy kultury doświadczają jej i jak kształtuje się wizerunek artysty. Odrzucenie mitu jedynego właściwego znaczenia nadawanego artyście i dziełu oraz możliwości tylko jednej interpretacji nie oznacza bowiem przyjęcia automatycznie opcji o pełnej dowolności dekodowania symboli związanych $\mathrm{z}$ artystą $\mathrm{i}$ jego dziełem. Przedstawione $\mathrm{w}$ artykule rozważania wskazują zatem na wewnętrzną złożoność nie tylko kategorii tożsamości, ale i wizerunku artysty, a także implikują potrzebę kolejnych analiz i badań empirycznych, których celem byłoby zidentyfikowanie postaw artystów wobec wykorzystywania marketingowego podejścia do kształtowania ich wizerunku oraz rozpoznanie zakresu subiektywizmu w odbiorze przez uczestników kultury działań podejmowanych przez twórców.

\section{Bibliografia}

Anand N., Watson M.R. (2004), Tournament Rituals in the Evolution of Fields: The Case of the Grammy Awards, „Academy of Management Journal”, Vol. 47, No 1, s. 59-80. 
Baldwin E., Longhurst B., McCracken S., Ogborn M., Smith G. (2007), Wstęp do kulturoznawstwa, tłum. M. Kaczyński, J. Łoziński, T. Rosiński, Poznań: Zysk i S-ka.

Brzezińska A. (2006), Dzieciństwo i dorastanie: korzenie tożsamości osobistej i społecznej, [w:] A.W. Brzezińska, A. Hulewska, J. Słomska (red.), Edukacja regionalna, Warszawa: Wydawnictwo Naukowe PWN, s. 47-77.

Colbert F. (2007), Marketing Culture and the Arts, Montreal: HEC.

Deuchert E., Adjamah K., Pauly F. (2005), For Oscar Glory or Oscar Money?, „Journal of Cultural Economics", Vol. 29, Issue 3, s. 159-176.

Dewalska-Opitek A. (2010), Model kreowania zintegrowanego wizerunku przedsiębiorstwa, „Zeszyty Naukowe. Polityki Europejskie, Finanse i Marketing”, nr 3 (52), s. 219-229.

Diggles K. (1986), Guide to Arts Marketing: The Principles and Practice of Marketing as They Apply to the Arts, London: Rhinegold Publishing.

Dragićević-Šešić M., Stojković B. (2010), Kultura: zarządzanie, animacja, marketing, tłum. J. Ambroziak, Warszawa: Narodowe Centrum Kultury.

English J.F. (2013), Ekonomia prestiżu, tłum. Ł. Zaremba, Warszawa: Narodowe Centrum Kultury. Geertz C. (2005), Interpretacja kultur. Wybrane eseje, tłum. M. Piechaczek, Kraków: Wydawnictwo Uniwersytetu Jagiellońskiego.

Golka M. (2013), Socjologia kultury, Warszawa: Wydawnictwo Naukowe Scholar.

Griswold W. (2013), Socjologia kultury. Kultury i społeczeństwa w zmieniającym się świecie, tłum. P. Tomanek, Warszawa: Wydawnictwo Naukowe PWN.

Grzegorczyk A., Kopeć T. (2013), Z talentem do gwiazd. Jak robić karierę w show-biznesie, Gliwice: Helion.

Harvey M., Evans M. (2001), Decoding Competitive Propositions: a Semiotic Alternative to Traditional Advertising Research, „International Journal of Market Research”, Vol. 43, Issue 2, s. 1-12.

Ilczuk D. (2012), Ekonomika kultury, Warszawa: Wydawnictwo Naukowe PWN.

Kapferer J.N. (2008), The New Strategic Brand Management. Creating and Sustaining Brand Equity Long Term, London-Philadelphia: Kogan Page.

Krzyworzeka P. (2017), Nagrody biznesowe. Etnografia rytuałów merytokracji, Warszawa: Poltext. Mazurek-Łopacińska K. (2015), Rola kodów kulturowych i zachowań konsumentów w kreowaniu innowacji, „Marketing i Rynek”, nr 2 [CD], s. 26-36.

Mazurek-Łopacińska K., Sobocińska M. (2014), Badania kodów kulturowych w tworzeniu marketingowych modeli biznesu, „Prace Naukowe Uniwersytetu Ekonomicznego we Wrocławiu”, nr 336: Badania marketingowe - nowe podejścia oraz metody na wspótczesnym rynku, s. 11-21.

Mokwa M.P., Dawson W.M., Prieve E.A. (eds.) (1980), Marketing the Arts, New York: Praeger Publishers.

Pawłowski R. (2017), Anatomia skandalu, „Notatnik Teatralny”, nr 84-85, s. 110-124.

Polak K., Żurawicka M. (2015). Badania semiotyczne i ich praktyczne wykorzystanie, [w:] A. Dąbrowska, A. Wódkowski (red.), Badania marketingowe. Praktyka nauce -nauka praktyce, Warszawa: Instytut Badań Rynku, Konsumpcji i Koniunktur, s. 110-120. 
Popiel M. (2011), Artysta awangardowy - między arcyludzkim a nieludzkim. Próba estetyki antropologicznej, „Teksty Drugie”, nr 6, s. 49-74.

Przastek D. (2017), Skandale teatralne w Polsce, „Notatnik Teatralny”, nr 84-85, s. 88-107.

Smoleń T. (2017), Elementy tożsamości marki instytucji na rynku kultury - analiza składowych w oparciu o model sześciokąta tożsamości marki J.N. Kapferera, „Marketing i Rynek”, nr 9, s. 365-372.

Sobocińska M. (2015), Uwarunkowania i perspektywy rozwoju orientacji rynkowej w podmiotach sfery kultury, Wrocław: Wydawnictwo Uniwersytetu Ekonomicznego we Wrocławiu. Szlendak T. (2013), Kultura nadmiaru w czasach niedomiaru, „Kultura Współczesna”, nr 1, s. 7-26. Varbanova L. (2013), Strategic Management in the Arts, New York: Routledge.

Witczak I. (1998), Istota i strategia wizerunku firmy, „Handel Wewnętrzny”, nr 6, s. 7-13.

Wojcik K. (2005), Public Relations. Wiarygodny dialog z otoczeniem, Warszawa: Placet.

Worcester R.M. (1986), Corporate image research, [w:] R.M. Worcester, J. Downham (eds.), Consumer Market Research Handbook, Amsterdam: ESOMAR, s. 601-616.

Wróblewski Ł. (2017), Culture Management. Strategy and Marketing Aspects, Berlin: Logos Verlag Berlin. 